\title{
Non-timber Forest Products Governance for Improved Rural Livelihood in Nigeria
}

\author{
Adedayo Adesoji Gideon \\ Department of Forestry and Wood Technology, Federal University of Technology, Akure, Nigeria \\ Email address: \\ agadedayo@futa.edu.ng, gieonadedayo@yahoo.com

\section{To cite this article:} \\ Adedayo Adesoji Gideon. Non-timber Forest Products Governance for Improved Rural Livelihood in Nigeria. American Journal of \\ Agriculture and Forestry. Vol. 6, No. 1, 2018, pp. 12-17. doi: 10.11648/j.ajaf.20180601.12
}

Received: December 17, 2017; Accepted: January 2, 2018; Published: February 1, 2018

\begin{abstract}
Despite the significant contributions of NTFPs to the livelihood of the people there is no clear policy directed at its exploitation in the country. It is considered as minor or secondary forest products. In addition the management of many NTFPs has been neglected over the years by foresters and economic planners. Hence NTFPs have not been developed. Its management has been restricted to the local people and urban poor. It is however important that if the contribution of NTFPs to rural livelihood is to be improved, then access to it and its exploitation needs to be properly understood. It is in view of this that this paper takes a look at the theoretical framework concerning Non- timber Forest Products (NTFPs) governance and its role in improving rural livelihood in Nigeria. It shows that NTFP governance has to do with the process of rule and decision making concerning production and marketing of NTFPs. It ensures equity of access and benefits obtainable from the exploitation of NTFPs. In doing this NTFPs governance help to promote sustainable forest management, protect forest resources from destructive use, promote communal peace, improves income earnings of rural dwellers and promotes increased rural well-being with the aim of helping to preserve the forest and by extension help to support rural livelihoods especially primary livelihoods like farming, hunting and fishing.
\end{abstract}

Keywords: Non-Timber Forest Products, NTFP Governance, Rural Livelihood and Nigeria

\section{Introduction}

From time immemorial forests have been providing many useful products to man. These products vary from timber products to fruits, ropes, leaves, honey and medicinal products. Among the diverse products provided by the forests NTFPs represents a significant part. NTFPs have been playing significant roles in the livelihoods of many rural households not only in Nigeria but all over Africa. NTFPs provide small but significant sources of income, particularly for women and for families that do not have access to agricultural markets [1]. Non- timber forest products, often referred to as NTFPs, are an important aspect of forests and forest use in many parts of the world. In addition to timber, paper, and bio energy, a number of products are extracted from forests that have important local and economic uses, and have been, suggested by researchers and some environmental NGO's and agencies to offer additional economic benefits for local communities [2]. NTFPs also provide critical supplies of food during periods when agricultural crops fail or are otherwise scarce. NTFPs are so important that at a time NTFPs were seen as a possible 'magic bullet' to solve deforestation issues [1].

It is however unfortunate that despite the significant roles of NTFPs to rural livelihoods its contributions have been largely neglected by policy makers and development planners. Oyun [3] noted that despite the significant roles of NTFPs, there is no clear policy directed at NTFPs at any level of government in Nigeria. It is considered as minor or secondary forest products. In addition the management of many NTFPs has been neglected over the years by foresters and economic planners. Hence NTFPs have not been developed. Its management has been restricted to the local people and urban poor.

It therefore, follows that if the contribution of NTFPs to rural livelihood is to be improved, then access to it and its exploitation needs to be properly understood. As noted by Belcher et al. [4] understanding of the role and potential of NTFPs to contribute to livelihood improvement and conservation objectives has been hindered by a lack of a clear theoretical framework and a functional typology of cases. This 
paper therefore tries to provide a clear theoretical framework about NTFPs and their governance with a view to creating a clear understanding about NTFPs that help to improve their exploitation and contribute more to rural livelihood.

\section{Concept of NTFPs}

Non-timber forest products (NTFPs) are biological resources other than timber, which are harvested from either natural or managed forests. Examples include fruits, nuts, oil seeds, latexes, resins, gums, medicinal plants, spices, wild life and wild life products. Others are dyes, ornamental plants, poles, raw materials such as bamboo and rattan [5]. Wickens [6] also defined NTFPs as all biological materials (other than industrial round wood, derived sound timber, wood chips, wood based panels and pulp) that may be extracted from natural ecosystem, managed plantations and be utilized within the household, be marketed or have social, cultural and religious significance. Chamberlain et al. [7] defines NTFPs as plants, parts of plants, fungi and other biological materials that are harvested from within and on the edge of natural, manipulated or disturbed forests. Non-timber forest products include fungi, Moss, Lichen, herbs, vines, shrubs or trees. Many different parts are harvested including the roots, tubers, leaves, bark, fungi, branches, resin, fruits, seeds as well as the wood. NTFPs are plants and plant materials used for food, fuel, storage fodder, and medicine etc. [8]. Non-timber forest products (NTFPs) are biological resources of plant and animal origin, harvested from natural forests, man made plantations, wooded land, farmlands, and trees outside forests and or domesticated. These products are vital sources of income, nutrition and sustenance for many forest-based communities around the world [9]. NTFPs are highly valued either for their leaves, roots, barks or fruits. They are the forest treasure that sustains rural dwellers by providing income, foods and medicinal materials. As a matter of fact majority of the rural poor all over Africa would have been showing obvious signs of malnutrition if not for the food provided by NTFPs to them inform of forest fruits and vegetables. NTFPs that serve as food help to supplement and complement the daily diet of the rural poor.

The list of NTFPs in Nigeria is wide and varied. Adedayo [10] noted that the list cannot be exhausted and its distribution depends on geographical region and climate which dictates the type of vegetation in an area. Table 1 gives a list of NTFPs that are collected from the tropical rain forest zone of Nigeria and the ir uses. The product satisfy various needs which include: food, shelter, fuel wood, medicine, craft, income, containers, rituals, chieftaincy and decoration.

Generally, NTFPs can be used for the following purposes: (i) firewood (ii) food (iii) medicinal (iv) charcoal (v) bush meat (vi) vegetable (vii) fruit (viii) chewing stick (ix) gum and adhesive (x) sweeteners (xi) dyes (xii) nuts (xiii) containers (xiv) fibres (xv) beverages and drinks (xvi) mushroom (xvii) honey (xviii) tannin (xix) aboricide and aphrodisiac (xx) wrapping leaves (xxi) fence (xxii) poles (xxiii) wattles (xxiv) beautification and decoration (xxv) fodder (xxvi) green manure (xxvii) soil and water conservation (xxviii) shelter (xxix) abatement of noise (xxx) wind break (xxxi) air sequential i.e.. air purification [11].

Table 1. Non-timber Forest Products commonly collected and used in the tropical forest zone of Nigeria.

\begin{tabular}{|c|c|c|c|}
\hline Common Name & Scientific Name & Part Used & Specific Use \\
\hline Firewood & ------------------------ & Stem, branches & Fuel \\
\hline Mushroom (Olu) & Agaricus bisporu & Strips & Food \\
\hline Honeybee (Oyin) & Apis mellifera & Honey & Food \\
\hline Snail (Igbin) & Archantia nmarginata & Fleshy parts & Food \\
\hline Bamboo (Oparun) & Oxytenanthera albyssisica & Stem & Craft and fuel wood \\
\hline Raphia palm & Raffia hooker & Juice, fronds & Wine \& craft \\
\hline Ogbono (seeds) & Irvingia gabonenesis & Seeds & Food \\
\hline Bitter cola (orogbo) & Garcina cola & Fruit & Food \\
\hline Butterfly larva (Eruku) & Anaphe venata & Pupa & Food \\
\hline Wrapping leaves (Eweiran) & Thaumatoccoccus danielli & Leaves & For wrapping food \\
\hline Walnut (asala) & Tetracapidium conophorum & Fruit & Food and medicinal \\
\hline Bitter leaves (Ewuro) & Vernonia amygadalna & Leaves & Food and medicinal \\
\hline Waterleaf & Talinum trangulane & Leaves & Food and medicinal \\
\hline Afon (seeds) & Treculia africana & Seeds & Food and medicinal \\
\hline Grass cutter (cane rat) & Thryonomys swinderiques & Whole part & Food \\
\hline Bush fowl (Aparo) & Francolinus bicakaratus & Whole part & Food \\
\hline Duiker (Etu) & Cephalophus spp & Whole part & Food \\
\hline Gambiasun squirrel (Okere) & Protezerus strangerri & Whole part & Food \\
\hline Gabon viper (Snake) & Biti gabonica & Whole part & Food \\
\hline
\end{tabular}

Source: Oyun [2]

\section{NTFPs Governance Concept}

Non-timber forest product (NTFP) governance is a concept that denotes the process of rule and decision making concerning production and marketing of NTFPs. It is more than rule making. It includes a broader societal process based on social practices, values and principles [12]. This process is 
characterized by the coexistence of formal and informal institutions based on plural statutory, customary and market norms. Ros-Tonen and Kusters [13] also defined NTFP governance as the multi-stake holder and multi level process of interactive decision making and creation of institutional frameworks for the allocation, use and trade of NTFPs. The concept of NTFP governance emerged as an analogous to the older concept of forest governance: a process that defines the purposes for which forests are managed and the conditions under which different stakeholders have access to decisionmaking and implementation processes [14].

Kooiman and Bavinck [15] use the term 'interactive governance' to refer to the interactive process between actors from the state, private sector and / or civil society at multiple scales aimed at 'solving societal problems and creating societal opportunities.' They distinguish between hierarchical governance, co-governance and self-governance, which correspond with Arts and Visseren- Hamakers' [16] distinction between governing by, with and without the state respectively. Forest governance was a concept that evolved out of the need to devolve the management of forest resources. It involves planning, utilizing and managing forest lands and resources through joint efforts of forest officials and the local community dwellers [17]. It is important that forest policies especially that of governance be tailored in a way that the primary focus will be on maintaining sustainability of the forest and at the same time meeting the needs of the local community dwellers living close to the forest. Neumann and Hirsch [18] noted that it is difficult to conceive of developing principles for NTFP harvesting equivalent to those associated to harvesting of timber. Nevertheless what makes NTFPs different from timber and important as a conservation strategy is the assumption that the forest remains mostly intact and more or less biologically intact under sustained NTFP harvesting. This accounts for much attention given to commercial NTFPs as the foundation upon which to build policies of conservation and development [18]. According to Brown et al. [19] local governance of NTFPs plays important role in reconciling concerns about dwindling forest resources and poverty among forest dwelling people. The dwindling forest resources and poverty among the forest dwelling people was a concern because it was thought that poor people may result to massive exploitation of NTFPs which may have negative impact on the forest ecosystem. However commercial exploitation of NTFPs has been recognized as an activity that has minimal impact on the forest [20] and it can as well play important role as a source of food and a source of income in situations where alternative livelihood activities are scarce [21].

It is important to note that the concept of NTFP governance was given prominence due to much attention that has been given to NTFPs recently. Non -timber Forest products (NTFPs) have for long been neglected by development planners in the development plans for Nigeria. Attention has majorly been focused on timber products. However in the past few decades attention has changed to NTFPs. It seems foresters and development planners have suddenly realized the importance of NTFPs more than ever before in the support of many livelihoods and in the supply of many benefits to many people. Some of the benefits include medicinal, cultural and social including provision of income to many forest dependent people. Belcher et al. [4] noted that increased interest in NTFPs began in the late 1980s and early 1990s in conjunction with increasing global concern about environmental issues especially deforestation, with increased attention on rural poverty and with the emergence of the concept of sustainable development.

\section{Ways NTFP Governance Can Improve Rural Livelihood}

Common rural livelihoods in Nigeria include farming, hunting, fishing, handcraft, goldsmithing and blacksmithing. One prominent characteristics of these livelihoods is that they are small scale and of low income [22]. This has not augured well with many rural dwellers in Nigeria. As a matter of fact this has been the core reason why many rural dwellers are poor and live in a state of hopelessness. It therefore follows that there must be a better way of utilizing NTFPs in order to improve the income earning potentials of NTFPs to the rural dwellers.

Among other things NTFP governance can help to improve rural livelihood through the following ways;

\subsection{NTFP Governance Promotes Sustainable Forest Resources Management}

Sustainable forest resources management is critical to ensuring sustainable rural livelihood. Warner [23] noted that sustainable use of natural resources is critical to sustainable livelihoods. He stated further that forests contribute to livelihoods by providing materials for construction, baskets, storage structures, agricultural implements, boats and hunting and fishing gear. They provide inputs for farming system such as fodder and mulch, contribute to soil nutrient cycling, help to conserve soil and water and provide shelter and shade for crops and animals. NTFP governance promotes sustainable forest management because it involves rural dwellers in the management of NTFPs. This help to promote their sense of belonging and their readiness to be involved in the protection of forest resources generally. This help to boost sustainable forest resources management which in turn helps to support rural livelihoods. It should be noted that sustainable agriculture is not possible without sustainable forestry. Sustainable forestry is not possible without proper protection of the forest and proper protection of the forest is not possible without the involvement of rural dwellers. The reason is because rural dwellers know the local terrain where forest reserves are located better than government employed forest guards. They are therefore in a better position to secure forest reserves than government employed forest guards.

\subsection{NTFP Governance Help to Protect Forest Resources}

NIFP governance can help to protect forest resources from destructive use. Though this might be an indirect role of NTFP governance, it is still a very important role of NTFP 
governance. This is because NTFP governance will make rural dwellers to see themselves as partners in progress with government over the management of forest resources located on their land. The reason for this is because NTFP governance will help to improve the sense of belonging among rural dwellers for the mere fact that they are involved in the management and sharing of benefits of NTFPs on their land. This will help to change their orientation and attitude towards forest resources generally. Hitherto many rural dwellers used to have a wrong notion that government's property is nobody's' property and as such it is subject to destruction and sometimes looting NTFP governance will therefore help to boost the morale of rural dwellers in the protection of forest resources generally. When forest resources are protected from destructive use they help to support many other rural livelihoods especially farming and hunting.

\subsection{NTFP Governance Help to Promote Communal Peace}

Peace is a phenomenon that every society strives to have. This is because peace brings development and progress to the society. As a matter of fact businesses as well as forest management and other rural livelihoods can only take place under a peaceful atmosphere. Achieving this peace seems to be a herculean task judging by the daily occurrence of conflicts. All over the country However NTFPs governance can help to bring peace through the involvement of members of the community in the taken of decisions in the management and utilization of NTFPs as well as in the sharing of the benefits. NTFP governance can help to bring peace by helping to prevent conflicting claims over ownership or access to NTFPs and by extension other forest resources. This role of NTFP governance is an unquantifiable role which is of extreme importance.

\subsection{NTFP Governance Help to Improve Income Earnings of Rural Dwellers}

Over the last two decades, the significant role of various forest products for rural household's income, food and livelihood security and support is increasingly recognized and a lot of emphasis was given to the Non -Timber Forest Products (NTFPs). In fact for, for a large number of people of the world NTFPs are more important forest resources than timber [24] (Olaitan et al. 2016). It is important to note that livelihoods are expected to be able to provide income that will meet the basic necessities of life. However the dwindling forest estate in the country has reduced drastically the capacity of rural livelihoods in providing income at a level that will meet basic rural household needs. As such many rural livelihoods are no longer sustainable due to low income generation and reduced forest estate. It is known that the forest estate help to support rural livelihoods both directly and indirectly. The reason for this is not unconnected with the fact that majority of the rural livelihoods are primary livelihoods. That is they are dependent on land and forest. It therefore follows that forest degradation affects rural livelihood. This shows that the state of the forest has both direct and indirect influence on rural livelihoods. Exploitation of NTFPs is known to have a minimal impact on forest degradation. Peters et al. [20] noted that exploitation of NTFPs has a minimal impact on the forest. It therefore follows that the exploitation of NTFPs can be used to preserve the forest which in turn will help rural livelihood. NTFP governance can then be used to improve rural livelihoods by helping to improve the income generated by rural households from their livelihood. Although NTFPs may not be the most important income generating products for local people living close to the forests, they contribute significantly to household income, food security, and house hold health care as well as, provision of multiple social and cultural values [25 and 26]. Sunderlin et al [21] noted that exploitation of NTFPs plays an important role for the rural poor as gap filler and source of income in situations where alternative livelihood activities are scarce. Table 2 shows that rural households in Ondo State made varying amount of incomes from NTFPs. Majority of rural households realized more than N40,000.00 from forest fruits and medicinal plants. Researches have shown that local governance of NTFPs can play significant role in poverty reduction and improved livelihood among rural households [19, 27 and 3].

Table 2. Estimate of annual income rural households realized from the sales of NTFPs in Ondo State Nigeria.

\begin{tabular}{|c|c|c|c|c|c|c|c|c|c|c|c|c|}
\hline \multirow{2}{*}{ NTFPs } & \multicolumn{2}{|c|}{$<\mathbf{N 2 0 , 0 0 0}$} & \multicolumn{2}{|c|}{$\$ 21,000-40,000$} & \multicolumn{2}{|c|}{$\$ 41,000-60,000$} & \multicolumn{2}{|c|}{ 丹61,000-80,000 } & \multicolumn{2}{|c|}{$£ 80,000-100,000$} & \multicolumn{2}{|c|}{$\$ 10,001-12,00$} \\
\hline & $\mathbf{N}$ & $\%$ & $\mathbf{N}$ & $\%$ & $\mathbf{N}$ & $\%$ & $\mathbf{N}$ & $\%$ & $\mathbf{N}$ & $\%$ & $\mathbf{N}$ & $\%$ \\
\hline Fuel wood & 10 & 4 & 29 & 12 & 67 & 28 & 91 & 38 & 10 & 4 & 0 & 0 \\
\hline Bush meat & 0 & 0 & 0 & 0 & 0 & 0 & 19 & 8 & 36 & 15 & 60 & 25 \\
\hline Wild fruits & 48 & 20 & 137 & 57 & 154 & 64 & 62 & 26 & 34 & 14 & 0 & 0 \\
\hline Medicinal plants & 43 & 18 & 187 & 78 & 50 & 21 & 10 & 4 & 0 & 0 & 0 & 0 \\
\hline Wrapping leaves & 19 & 8 & 34 & 14 & 74 & 31 & 12 & 5 & 0 & 0 & 19 & 8 \\
\hline Bamboo & 0 & 0 & 0 & 0 & 10 & 4 & 5 & 2 & 14 & 6 & 0 & 0 \\
\hline Vegetables & 58 & 24 & 127 & 53 & 5 & 2 & 0 & 0 & 0 & 0 & 0 & 0 \\
\hline Honey & 0 & 0 & 22 & 9 & 31 & 13 & 0 & 0 & 0 & 0 & 0 & 0 \\
\hline Chewing sticks & 17 & 7 & 31 & 13 & 17 & 7 & 10 & 4 & 0 & 0 & 0 & 0 \\
\hline Snails & 31 & 13 & 115 & 48 & 53 & 22 & 10 & 4 & 0 & 0 & 0 & 0 \\
\hline Raffia palm wine & 0 & 0 & 14 & 6 & 36 & 15 & 31 & 13 & 10 & 4 & 0 & 0 \\
\hline Mushroom & 38 & 16 & 149 & 62 & 50 & 21 & 22 & 9 & 0 & 0 & 0 & 0 \\
\hline
\end{tabular}

Source: Adapted from Falade, et al. [28]. 


\subsection{NTFP Governance Promotes Increased Well-Being}

NTFP governance help to promote increased well being among rural dwellers. Increased well being of rural dwellers can have both direct and indirect impact on rural livelihoods. When the well-being of rural dwellers is increased it will also affect the well-being of the forest. This in essence means the forest will be preserved. NTFP governance can improve people's well-being by improving their access to resources, increase their income as well as self esteem and political power. Warner [23] noted that sense of well -being is affected by numerous factors including self esteem, sense of control and inclusion, health status, access to services and political enfranchisement. He went further to state that forestry initiatives that support access to resources, particularly decision making and equity assist in increasing well-being, especially that of the poor. This is exactly what NTFP governance does. It supports access of rural dwellers to NTFPs and ensures equity in the distribution of benefits there by helping to increase their income. This is particularly important considering the fact that in recent decades, there has been growing interest in the contribution of non-timber forest products (NTFPs) to livelihoods, development, and poverty alleviation among the rural populace. This has been prompted by the fact that communities living adjacent to forest reserves rely to a great extent on the NTFPs for their livelihoods [29]. This has helped to increase their well-being to a great extent. The significance of this is that increased well-being among rural dwellers will help to reduce deforestation and other forms of forest destructive use. Sheperd [30] noted that it is beginning to be accepted that the well-being of the forests and the people heavily dependent upon them, are closely intertwined. In the same vein de Ceara [31] noted that the only means of stabilizing the ecosystem is to stabilize the social system; to solve the deforestation problem one must solve the poverty problem. From the fore going it therefore follows that NTFP governance will help to support forest conservation and by extension it will help to support primary rural livelihoods like farming, hunting and fishing.

\section{Conclusion}

This study has shown that NTFP governance is a concept that seeks the involvement of members of the community in the management and taking of decisions on the use of NTFPs as well as sharing of the benefits derivable. In doing this NTFP governance help to support sustainable forest resources management, it helps to protect forest resources from destructive use, promote communal peace, improves income earnings of rural dwellers and promotes increased rural well-being. All these roles of NTFP governance help to preserve the forest and by extension help to support rural livelihoods especially primary livelihoods like farming, hunting and fishing.

\section{References}

[1] Central African Regional Programme for the Environment (CARPE) (2001): Non-Timber Forest Products Economics and Conservation Potential. Comgo Basin Information Series Issue Brief No 10 March, 2001. Pp. 10.

[2] Global Forest Atlas (2017). Non-timber Forest Products. https//globalforestatlas.yale.edu. Cited on 29 December, 2017.

[3] Oyun, M. B. (2009): The Role of Non-timber Forest Products on the Livelihoods of Fringe Communities of Idanre Forest Reserve, Nigeria. Forests and Forest Products Journal, 2:6-75, 2009.

[4] Belcher. B., M. Ruiz Pérez and R. Achdiawan (2005) 'Global patterns and trends in the use and management of commercial NTFPs:implications for livelihoods and conservation.' World Dev 33 (9): 1435-1452.

[5] Nguyen, T. N. and Bui, T. A. (2000): Non-Timber Forest Products (NTFPs)-Gender Analysis \& Gender Action Plan. NTFP Project, 8 Chuong Duong Do, Hanoi, Vietnam, 2000.

[6] Wickens, G. E. (1991) Management issues for development of non-timber forest products. Unasylva 42(165):3-8.

[7] Chamberlain, J. L., Bush, R. and Hammett, A. L. (1998): NonTimber Forest Product: The other Forest Products. Forest Product Journal. 48 (10):2-12.

[8] Idumah, F. O. Onyeanusi, A. E. and Ajayi, C. A (2008): NonTimber Forest Resources and Sustainable Livelihood in a Rural Economy. In: Agbogidi, O. M (Ed): Proceedings of the $2^{\text {nd }}$ Biennial National Conference of the Forests and Forest Product Society. $26^{\text {th }}-29^{\text {th }}$ April, 2010. Pg. 372-378.

[9] Solomon, M. M. (2016). Importance of Non Timber Forest Production in Sustainable Forest Management and Its Implication on Carbon Storage and Biodiversity Conservation in Case of Ethiopia. J Biodivers Endanger Species 4:160. doI: 10.4172/2332-2543.1000160.

[10] Adedayo, A. G. (2017). Harnessing the Food Potentials of NTFPs for Food security in Nigeria's Rural Communities.: In: O. A. Fagbenro and B. N. Ejidike (eds.) Proceedings of the $6^{\text {th }}$ Internaional Conference / workshop on Giant African Land Snails (NetGALS). Snail: Harnessing Bio-Resources for food security and National Development. Held at the Federal University of Technology, Akure, Nigeria. June 4th-7th, 2017. Pp. 20-24.

[11] Etukudo, I. (2000): Forest-Our Divine Treasure. Dorand Publishers, Uyo. Pp. 250.

[12] Wiersuma, K. F., Ingramb, V. J. and Ros-Tonen, M. A. F. (2015). Governing access to resources and markets in nontimber forest product chains. Forests, Trees and Livelihoods. http://dx.doi.org/10.1080/14728028.2013.868676.Cited on 2706-2015.

[13] Ros-Tonen, M. A. F. and Kusters, K. (2011). Pro-poor governance of non-timber forest products: the need for secure tenure, the rule of law, market access and partnerships. In: Shackleton S, Shackleton C, Shanley P, editors. Non-timber forest products in the global context. 1sted. Heidelberg: Springer Tropical Forestry Series, 7: 189-207 
[14] Lemos, M. C. and Agrawal, A. (2006). 'Environmental governance', Annu Rev Environ Resour, 31: 297-325.

[15] Kooiman, J. and Bavinck, M. (2005). The governance perspective. In: Kooiman J, Bavinck M, Jentoft S, Pullin R, (editors). Fish for life: Interactive governance for fisheries. Amsterdam: Amsterdam University Press (MARE Publication Series vol. 3). Pp. 11-24.

[16] Arts B, V. and Visseren -Hamakers, I. (2012). Forest governance: a state of the art review. In: Arts B, van Bommel S, Ros -Tonen M, Verschoor G, editors. Forest - people interactions: understanding community forestry and biocultural diversity. Wageningen: Wageningen Academic Publishers. pp. 241-257.

[17] Akinola, S. R. (2006). Land Use Decree, Forest Administration and Governance crises in Nigeria. Http/www.fig.net/pub/accra/papers//ts01/ts01_04_akinolapdf.

[18] Neumann, R. P. and Hirsch, E. (2000) Commercialization of non-timber forest products: Review and Analysis of Research, Bogor: Center for International Forestry and Rome: FAO.

[19] Brown, D, M. Schreckenberg, G. Shepherd and A. Wells (2002): Forestry as an entry point for governance reform. ODI Briefing Paper 2002 (1).

[20] Peters, C. M., A. H. Gentry and R. O. Mendelsohn (1989) 'Valuation of an Amazonian Forest', Nature 339:655-656.

[21] Sunderlin, W., Angelsen, A., Belcher, B., Burgers, P., Nasi, R., Santoso, L. and Wunder, S. (2005). 'Livelihoods, forests, and conservation in developing countries: an overview. World Development, 3 (9): 1383-1402.

[22] Adedayo, A. G. (2002). Forest Resources Utilization and its impact on Rural Livelihood in Kwara State, Nigeria. Unpublished M. Agric. Tech Thesis of the Department of Forestry and Wood Technology, Federal University of Technology Akure, Nigeria. 146pp.

[23] Warner, K. (2000): Forestry and Sustainable Livelihood. Unasylva2 02 vol. 51 (1) 3-12.

[24] Olaitan, A. O., Plaifa, K. A., Asinwa, A. O., Sulaiman, O. N. and Ojo, P. A. (2016). Contribution of NTFPs to Livelihoods in Wetlands Southern Nigeria. In: O. Y. Ogunsanwo, and A. O. Akinwole (eds.) Proceedings of the 38 th Annual Conference of the Forestry Association of Nigeria. Mangroves and Wetlands of Sub -Saharan Africa: Potential for Sustainable Livelihoods and Development. Heldin PortHarcourt, River State, Nigeria between $7^{\text {th }}-11$ th March, 2016. Pp. 298-305.

[25] Ojea E, Loureiro M L, Alló M, Barrio M (2016) Ecosystem services and REDD: estimating the benefits of non- carbon services in worldwide forests. World Dev 78: 246-261.

[26] Endamana D, Angu K A, Akwah G N, Shepherd G, Ntumwel B C (2016) Contribution of non- timber forest products to cash and non- cash income of remote forest communities in Central Africa. Int. For. Rev. 18 (3): 280-295.

[27] Mayers, J. and S. Vermeulen (2002) Power from the trees: how good forest governance can help reduce poverty, London: W S S D Opinion, I I E D.

[28] Falade, O. I; Adedayo, A. G. and Oyerinde, V. O. (2014). Collection and sales of Non- timber Forest Products (NTFPs) in Ondo State: Implications on Forest Estates. (Adedire, M. O., Onyekwelu, J. C., Oke, D. O. Adekunle, V. A. J. Jayeola, O. A. and Oladoye, O. A. -Editors ) Proceedings of the fourth Biennial National Conference of Forests and Forest Products Society, Federal University of Agriculture Abeokuta, Nigeria, 23-26 April 2014, pp. 424-49.

[29] Suleiman, M. S., Wasonga, V. O., Mbau, J. S. et al. (2017). Non-timber forest products and their contribution to households income around Falgore Game Reserve in Kano, Nigeria Ecological Processes (2017) 6:23. https://doi.org/10.1186/s13717-017-0090-8 Cited on 29 December, 2017.

[30] Shepherd, G. (1992): Forest Policies, Forest Politics. Publish by Overseas Development Institute Occasional Paper 13 London. Pp. 84.

[31] de Ceara, I. (1986): Land Tenure and Agroforestry in the Dominican Republic. Social Forestry Network Paper. 3d. Overseas Development Institute. 